\title{
ZASADNOŚĆ REWIZJI KONSTYTUCJI INSTYTUTÓW ZAKONNYCH ORAZ ICH ZAWARTOŚĆ I FORMA WEDŁUG DOKUMENTÓW KOŚCIELNYCH
}

Treść: Wprowadzenie. - 1. Aktualizacja czy rewizja konstytucji? 2. Uzasadnienie rewizji konstytucji. - 2.1. Dezaktualizacja pewnych form wyrażania charyzmatu oraz stosowanego w związku z tym słownictwa. 2.2. Zetknięcie instytutu $\mathrm{z}$ innymi kulturami. - 2.3. Odzwierciedlenie w konstytucjach eklezjalności życia zakonnego i apostolatu instytutu. - 2.4. Pneumatologiczny i trynitarny wymiar życia konsekrowanego. - 3. Aktualność posoborowych kryteriów rewizji konstytucji. - 4. Język i wewnętrzny podział tekstów prawnych. - 4.1. Ogólne zasady formułowania tekstów prawnych. - 4.2. Cechy języka prawnego. - 5. Redagowanie tekstu konstytucji według wskazań dokumentów kościelnych. - 5. 1. Normy z 1901 i 1921 roku. - 5.2. Kodeks Prawa Kanonicznego z 1983 roku. - 5.2.1. Zharmonizowanie elementów prawnych i duchowych konstytucji. - 5.2.2. Kwestie do zamieszczenia w zbiorach prawa własnego instytutu. - Zakończenie.

\section{Wprowadzenie}

Kodeksy fundamentalne instytutów zakonnych życia konsekrowanego, zwane najczęściej konstytucjami, powinny zawierać podstawowe zasady teologiczne i normy prawne, które wiernie odzwierciedlałyby charyzmat instytutów oraz ich dziedzictwo duchowe. Każdy zakonnik zobowiązany jest wiernie zachowywać, rozwijać i strzec wspomnianego dziedzictwa swego instytutu dotyczącego jego natury, celu, charakteru, ducha i zdrowych tradycji, dążąc tym 
samym do doskonałej miłości Boga drogą rad ewangelicznych w sposób wskazany przez założycieli inspirowanych przez Ducha Świętego. Stąd tak duże znaczenie ma wierne i komunikatywne oddanie w tych podstawowych zbiorach prawnych myśli i zamiarów założycieli. Konstytucje bowiem nie są zwykłą książką, jedną z wielu, którą po przeczytaniu odstawia się na półkę, lecz muszą stać się prawdziwą księgą życia, której treści członkowie instytutów zobowiązani są wciąż na nowo przyswajać i wprowadzać we własne życie - zarówno duchowe, jak i codzienną działalność. Ważną rolę odgrywa zatem sposób formułowania w konstytucjach zasadniczych kwestii i użyty w dokumencie język. Wspomniane zagadnienia będą stanowiły przedmiot niniejszego studium.

\section{Aktualizacja czy rewizja konstytucji?}

W ramach wskazanej przez Sobór Watykański II przystosowanej do współczesności odnowy życia zakonnego dużo miejsca poświęcono w instytutach zakonnych pracom nad rewizją prawa własnego obejmującego konstytucje i inne zbiory drugorzędne, np. dyrektoria, ustawy, typiki. Zgodnie z dekretem dotyczącym życia zakonnego pt. Perfectae caritatis prace zmierzały do usunięcia przestarzałych przepisów i dostosowania ich do dokumentów soborowych, które z kolei polecały zharmonizować takie dziedziny życia jak modlitwa i praca $z$ warunkami fizycznymi i psychicznymi współczesnych ludzi, a także - adekwatnie do charyzmatu instytutu - wymogami apostolskimi, kulturalnymi, sytuacją społeczną i ekonomiczną kraju ${ }^{1}$.

Celem przeprowadzenia tych i innych zmian w konstytucjach zalecano dokonanie odpowiedniego przeglądu czy inaczej rewizji własnego prawodawstwa (congruenter recognoscantur). Trzeba zauważyć, że włoska literatura stosuje termin rewizja prawa własnego, podczas gdy w Polsce przyjęło się używać nader często określenia aktualizacja,

\footnotetext{
${ }^{1}$ Soвór WAтүкаŃski II, Dekret o przystosowanej do współczesności odnowie życia zakonnego "Perfectae caritatis», nr 1 w: Sobór Watykański II, Konstytucje, dekrety, deklaracje. Tekst polski. Nowe tłumaczenie, Poznań 2002, s. 259-275 (odtąd PC).
} 
które, jak się wydaje, może prowadzić do błędnych konotacji, a co za tym idzie - do dokonywania niewłaściwych zmian prawa własnego. Termin ten może bowiem sugerować, że konstytucje przeżyły się, zestarzały, zdezaktualizowały co do swego głównego zamysłu, a więc charyzmatu założyciela oraz wynikającego z jego realizacji duchowego dziedzictwa instytutu, i wymagają uaktualnienia, dostosowania do współczesności. Tymczasem charyzmat założyciela i pochodzący od niego charyzmat instytutu, odzwierciedlając zawsze jakiś aspekt Ewangelii, podobnie jak sama Dobra Nowina nie przeżywa się i nie starzeje, jest wciąż aktualny - zmieniają się jedynie sposoby jego realizacji, formy wyrażania charyzmatu w nowych warunkach społecznych i kulturalnych. Te ostatnie wciąż ewoluują, natomiast charyzmat pozostaje niezmieniony od czasu udzielenia go przez Ducha Świętego założycielowi instytutu. Formy jego urzeczywistnienia wymagają nowego ujęcia w odpowiednich słowach - zrozumiałych dla młodszych pokoleń członków, co z kolei zakłada wcześniejsze krytyczne rozpatrzenie dotychczasowych przepisów, czyli ich rewizję.

Nie przeżyły się słowa papieża Pawła VI skierowane w 1967 roku do uczestników kapituły generalnej Zgromadzenia Redemptorystów, gdy zauważył, że odnowa życia zakonnego i prawa własnego ma zmierzać paradoksalnie do przeszłości, być powrotem do pierwotnego kształtu charyzmatu, jaki wycisnął na nim założyciel, i usunięcia tego wszystkiego, co wraz z upływem czasu wtargnęło do obserwancji instytutu i jest niewłaściwe, zbyteczne oraz przeżyło $\operatorname{się}^{2}$. Chociaż w języku polskim termin rewizja brzmi trochę obco, to jednak dzięki zastąpieniu nim określenia aktualizacja dałoby się w wielu przypadkach uniknąć

\footnotetext{
${ }^{2}$ Pawe VI, Przemówienie do uczestników kapituły generalnej Ojców Redemptorystów, 24.09.1967, w: Tenże, Charyzmat życia zakonnego. Przemówienia i dokumenty. Wybór i opracowanie A. Żuchowski, T. Sułowska, Poznań-Warszawa 1974, s. 151: „Chodzi raczej o takie dzieło odnowy, które ma usunąć to wszystko, co z biegiem czasu jako niewłaściwe, zbyteczne lub już przeżyte wtargnęło w waszą obserwancję”. Dzieło odnowy ma być tak dokonane aby Zgromadzenie „zajaśniało pierwotną wspaniałością i przybrało ów święty kształt i wyraz, jaki chciał na nim wycisnąć wasz Ojciec - Prawodawca. W ten sposób wprawdzie litera waszych reguł będzie mogła się zmienić, ale duch pozostanie nietknięty”.
} 
podczas odnowy konstytucji dostosowywania charyzmatu do współczesności zamiast współczesności do niezmiennego charyzmatu. Można by też uchronić instytut przed daleko idącymi zmianami w konstytucjach polegającymi na usuwaniu elementów życia, które jawią się jako nieaktualne, a raczej niemodne, chociaż stanowią istotę charyzmatu założyciela i w ogóle życia zakonnego, np. obowiązku zachowania klauzury, milczenia itp. Termin aktualizacja mógłby na przykład sugerować, że niektóre instytuty są przeżytkiem, jak np. Zakon Najświętszej Maryi Panny od Wykupu Niewolników założony w 1235 r. przez św. Piotra Nolasco, bo przecież czasy niewolnictwa dawno się skończyły. Tymczasem papież Pius XII w przemówieniu do jego członków powiedział, że chociaż obecnie nie ma potrzeby oswobadzania $\mathrm{z}$ niewoli ciała, to jednak charyzmat Zakonu jest nadal żywy, ponieważ wiele ludzi pozostaje w groźniejszej jeszcze niewoli, jaką jest grzech ${ }^{3}$.

\section{Uzasadnienie rewizji konstytucji}

Konstytucje instytutów zakonnych opracowane po Soborze Watykańskim II, a następnie dostosowane do wymagań Kodeksu Prawa Kanoniczego z 1983 roku, oparte są na solidnej bazie biblijno-teologicznej, a także pogłębionej refleksji dotyczącej charyzmatu założyciela oraz sposobów jego przeżywania i realizacji. Z nich wynikają pewne normy, także prawne, które nie są niezmienne, lecz pozostają wciąż otwarte „na bardziej wymagające interpretacje”, na możliwość rozwoju i odpowiednich przystosowan ${ }^{4}$. Przepisy konstytucji, oprócz opisu tożsamości instytutu, otwierają się także na przyszłość odpowiadającą charyzmatowi instytutu, na dar Ducha Świętego w nim wyrażony, na rozwój instytutu w syntonii ze wzrostem Ciała Chrystusa ${ }^{5}$.

3 PIUs XII, List Quandoquidem Christus, 19.01.1956, Acta Apostolicae Sedis 48 (1956), s. 81; Por. S.M. Eligia, Stan zakonny w Kościele w nauce papieży ostatnich czasów, Ateneum Kapłańskie 53 (1961), s. 95.

${ }^{4}$ Per una fedeltà perseverante, http://www.osservatoreromano.va/it/news/per-una-fedelta-perseverante [dostęp 20.11.2016 r.]

${ }^{5}$ Jan PAweŁ II, Posynodalna adhortacja apostolska o życiu konsekrowanym i jego misji w Kościele i świecie "Vita consecrata», nr 20, Warszawa-Ząbki 1996 (odtąd Vita 
2.1. Dezaktualizacja pewnych form wyrażania charyzmatu oraz stosowanego w związku z tym słownictwa

Może się zdarzyć, że charyzmatu instytutu już nie oddają w pełni pewne formy, w których został on kiedyś wyrażony, np. sposób modlitwy, realizacji rad ewangelicznych, sprawowania władzy, ascezy (chociażby stosowanie tzw. dyscypliny, czyli biczowanie się), życia braterskiego we wspólnocie, sposobu oddzielenia od świata itp. Także słownictwo stało się w pewnej mierze niezrozumiałe dla współczesnego człowieka (np. sufragia) wskutek rozwoju społecznego, kulturalnego, technicznego czy ekonomicznego. Konieczna jest wówczas rewizja praktyk modlitewnych i ascetycznych wypełnianych przez członków instytutu oraz języka zbiorów prawa własnego.

\subsection{Zetknięcie instytutu $\mathrm{z}$ innymi kulturami}

Do pewnych zmian w konstytucjach może skłaniać niektóre instytuty objęcie swym zasięgiem nowych obszarów kulturowych, któremu towarzyszy nazbyt często jednoczesne zmniejszenie liczby powołań w Europie, tak że Europejczycy stają się mniejszością wśród członków instytutu. Ponieważ jest to nowe zjawisko, obowiązujące dotychczas konstytucje nie uwzględniają sposobu realizacji charyzmatu w nowych kulturach np. Wschodu, Ameryki Północnej lub Azji. Wprowadzenie zmian wymaga prawdziwego dialogu interkulturowego zarówno wewnątrz instytutu, jak i ze społecznością, w której on istnieje, zmusza do uważnej refleksji nad uniwersalnymi wartościami charyzmatu całego instytutu, które muszą być odróżnione od właściwych dla tradycji kulturalnych Europy Zachodniej. Te ostatnie nie mogą być przeniesione do innych części świata, co wymaga odpowiedniej korekty w konstytucjach.

consecrta); A. Montan, Costituzioni: attenzioni giuridiche, Sequela Christi (2006) nr 02 , s. 172 . 


\subsection{Odzwierciedlenie w konstytucjach eklezjalności życia zakonnego i apostolatu instytutu}

Podejmowana w ostatnich dziesięcioleciach teologiczna refleksja nad naturą życia konsekrowanego doprowadziła do wniosku, że Kościół bez realizacji rad ewangelicznych, dzięki której uobecnia Chrystusa na ziemi, nie ukazywałby pełni życia Zbawiciela ${ }^{6}$. Także wśród osób konsekrowanych znacznie pogłębiła się świadomość eklezjalności życia konsekrowanego, jego istotnego znaczenia dla tajemnicy Kościoła, co z kolei znacznie zacieśniło związek zakonników z Kościołem. W konsekwencji sentire cum Ecclesia w różnych jego wymiarach znajduje coraz wyraźniejszy oddźwięk w konstytucjach instytutów ${ }^{7}$.

Może się też zdarzyć, że konstytucje w części dotyczącej działalności apostolskiej instytutu zostały zredagowane niezbyt jasno, powodując tym samym dużą niepewność wśród zakonników co do odpowiedzi na pojawiające się w społeczeństwie nowe prądy, które dają impuls do przyjrzenia się na nowo prowadzonemu przez instytut apostolatowi. Pod wpływem nacisków społecznych budzi się bowiem pokusa podejmowania prac bardzo różnorodnych albo atrakcyjnych i rozpraszanie tym samym energii instytutu na wielości zadań, a także pokusa porzucenia dotychczasowych dzieł właściwych instytutowi na rzecz bieżących potrzeb społecznych ${ }^{8}$. Jeśli w konstytucjach występują podobne niejasności, konieczne jest dokładniejsze wyrażenie działalności apostolskiej właściwej instytutowi, wynikającej z charyzmatu założyciela.

\footnotetext{
${ }^{6}$ Vita consacrata 3, 29, 105.

7 Kongregacja Instytutów Życia Konsekrowanego i Stowarzyszeń ŻyCia Apostolskiego, Instrukcja Posługa władzy i posłuszeństwo «Faciem tuam, Domine, requiram» Libreria Editrice Vaticana 2008, nr 13F (odtąd: Posługa władzy i posłuszeństwo).

${ }^{8}$ Święta Kongregacja Zakonów I Instytutów ŚwieCKICH, Instrukcja o istotnych elementach nauczania Kościoła na temat życia konsekrowanego w zastosowaniu do instytutów oddajacych się pracy apostolskiej «The renewal of religious life», $\mathrm{nr} 27$ w: Życie konsekrowane w dokumentach Kościoła. Od Vaticanum II do Ripartire da Cristo (red. K. Wójtowicz), Kraków 2003², s. 289-315.
} 


\subsection{Pneumatologiczny i trynitarny} wymiar życia konsekrowanego ${ }^{9}$

Życie konsekrowane przez profesję trzech rad ewangelicznych podejmowanych ze względu na Chrystusa w celu upodobnienia się do Niego jest też określane mianem sequela Christi i jasno ukazuje jego chrystocentryczny charakter. W ostatnich latach natomiast, zwłaszcza w adhortacji apostolskiej Vita consecrata wydanej w 1996 roku, podkreśla się też coraz bardziej rolę Ducha Świętego i trynitarny charakter życia konsekrowanego. W dokumencie przypomina się, że powołanie każdej osoby do tego rodzaju konsekracji, u którego początku jest zawsze inicjatywa Ojca, wiąże się bardzo mocno z działaniem Parakleta. Także w kolejnych latach formacji zakonnej Duch Święty odgrywa istotną rolę w stopniowym upodobnieniu się osoby konsekrowanej do Chrystusa. Realizacja rad ewangelicznych przez poszczególnych zakonników jako radykalne naśladowanie formy życia Chrystusa na ziemi świadczy jednocześnie o więzi istniejącej między zakonnikiem a Ojcem, Synem i Duchem Świętym ${ }^{10}$. „Dzięki takiemu upodabniającemu utożsamieniu się z tajemnicą Chrystusa życie konsekrowane w szczególny sposób urzeczywistnia ową confessio Trinitatis, która jest znamienną cechą całego życia chrześcijańskiego" ${ }^{11}$. Jan Paweł II we wspomnianej adhortacji pisze, że „życie konsekrowane jest głoszeniem tego, czego dokonuje Ojciec przez Syna w Duchu Świętym swoją miłością, swoją dobrocią, swoim pięknem" i staje się jednym z widzialnych śladów, które Trójca Święta pozostawia w historii, aby

\footnotetext{
${ }^{9}$ Vita consecrata 16; Kongregacja Instytutów Życia Konsekrowanego I Stowarzyszeń Życia Apostolskiego, Rozpocząć na nowo od Chrystusa: odnowione zaangażowanie życia konsekrowanego w trzecim tysiącleciu, Poznań 2002, nr 5 (odtąd: Rozpocząć na nowo).

${ }^{10}$ Vita consecrata $16,18$.

${ }^{11}$ Vita consecrata 16; Rozpocząć na nowo 20: „Przede wszystkim chodzi o to, by w myśl nauczania Vita consecrata żyć w pełni teologia rad ewangelicznych, biorąc wzór z życia Trójcy Świętej, z nową możliwością konfrontacji ze źródłami własnego charyzmatu i własnych tekstów".
} 
pobudzić ludzi do zachwytu nad pięknem Boga i obudzić w nich tęsknotę za Nim ${ }^{12}$.

Adekwatnie do nauczania Kościoła dotyczącego wspomnianych wymiarów życia konsekrowanego próbuje się również w konstytucjach instytutów wyjaśnić, pogłębić i wyrazić istotę konsekracji, na co pozwala obowiązujące prawodawstwo, zachęcając do harmonijnego połączenia w prawie własnym instytutów elementów prawnych $\mathrm{z}$ teologicznymi ${ }^{13}$.

\section{Aktualność posoborowych kryteriów rewizji konstytucji}

Wydaje się, że obecnie podczas dokonywania rewizji konstytucji zakonnych korzystne jest odwoływanie się nadal do wciąż aktualnego - mimo upływu lat - nauczania Concilium Vaticanum II, doświadczenia posoborowego oraz wydanych w ostatnich latach wskazań dokumentów kościelnych dotyczących życia konsekrowanego. Jasno wynika z nich podstawowa zasada, która winna przyświecać pracom nad badaniem prawa własnego: odnowa życia zakonnego bardziej zależy od dokładniejszego przestrzegania reguł i konstytucji niż od mnożenia przepisów i wydawania ciągle nowych norm ${ }^{14}$, ponieważ mnogość przepisów zwykle idzie w parze z lekceważeniem $i^{15}{ }^{15}$. Konieczna rewizja norm powinna natomiast polegać przede wszystkim na usunięciu przepisów przestarzałych oraz elementów

\footnotetext{
${ }^{12}$ Vita consecrata 20.

${ }^{13}$ KPK/1983, kan. $587 \$ 3$.

${ }^{14}$ PC 4: „Niech wszakże wszyscy pamiętają, że nadzieję odnowy należy pokładać raczej w dokładniejszym przestrzeganiu reguły i konstytucji aniżeli w mnożeniu przepisów".

${ }^{15}$ PAweŁ VI, Przemówienie do uczestników kapituł generalnych 23.05.1964, AAS 56(1964), s. 565-571, tekst polski w: Tenże, Charyzmat życia zakonnego. Przemówienia i dokumenty, opr. A. Żuchowski, T. Sułowska, Poznań-Warszawa 1974, s. 85-86. „Wzrost zaś zgromadzenia ma polegać raczej na wierniejszym zachowywaniu reguł niż na wzroście liczby członków lub wydawaniu nowych ustaw. Zresztą pomnażaniu nowych praw nie zawsze towarzyszy postęp w życiu zakonnym. Zdarza się bowiem często, że im więcej wydaje się przepisów, tym mniej się na nie zwraca uwagę. Dlatego kapituły generalne, posiadając władzę wydawania nowych ustaw, niech używają jej zawsze z umiarkowaniem i roztropnością”.
} 
obcych dla życia danego instytutu ${ }^{16}$. Przepisami przestarzałymi są takie, które nie stanowią o istocie oraz celu instytutu, a ponieważ utraciły swą dawną siłę i nie przemawiają do członków instytutów tak jak dawniej, nie służą im już pomocą ${ }^{17}$.

W adhortacji apostolskiej Vita consecrata zachęca się dziś raczej do „przemyślenia na nowo Reguły” i konstytucji niż do dokonywania zmian, ponieważ jest $\mathrm{w}$ nich zawarty program naśladowania Chrystusa określony dodatkowo i ukształtowany przez charyzmat instytutu ${ }^{18}$.

Częstszej rewizji mogą być poddawane drugorzędne zbiory prawa własnego, takie jak np. dyrektoria, statuty itp., ponieważ szybciej się dezaktualizują jako zawierające przepisy bardziej szczegółowe niż konstytucje, są też dostosowane do potrzeb i zwyczajów różnych prowincji tego samego instytutu.

\section{Język i wewnętrzny podział tekstów prawnych}

Wprawdzie siła i znaczenie konstytucji zakonnych polegają na ich wiernym wprowadzaniu w życie przez każdego członka i cały instytut, to jednak nie bez znaczenia pozostają ich forma językowa oraz kompozycja, których nie powinno się zaniedbać w czasie rewizji konstytucji.

\footnotetext{
${ }^{16}$ PC 3: „Dlatego też trzeba dokonać przeglądu konstytucji, „dyrektoriów”, ksiąg zwyczajów, modlitewników, ceremoniałów i innych książek tego rodzaju, a po usunięciu przepisów już przestarzałych, dostosować je do dokumentów wydanych przez ten święty Sobór”. Ecclesiae Sanctae III, $16 \S 3$ : „W trosce o dobro Kościoła, niech Instytuty zdobywają prawdziwe poznanie swego pierwotnego ducha tak, by zachowując go wiernie w przedsiębraniu przystosowań, oczyścić życie zakonne od obcych pierwiastków i rzeczy przestarzałych".

${ }^{17}$ PaweŁ VI, Motu proprio Ecclesiae Sanctae, w: Tenże, Charyzmat życia zakonnego. Przemówienia i dokumenty, opr. A. Żuchowski, T. Sułowska, Poznań-Warszawa 1974, III 1, s. 216-225 (odtąd Ecclesiae Sanctae).

${ }^{18}$ Vita consecrata 37.
} 


\subsection{Ogólne zasady formułowania tekstów prawnych}

Chociaż charyzmat odznacza się pewną nieprzewidywalnością, spontanicznością i jest rzeczywistością żywą, to jednak z drugiej strony wymaga uzewnętrznienia w postaci konkretnych form i norm ściśle powiązanych ze sobą, organizujących życie danego instytutu zakonnego. W ten sposób charyzmat może być skutecznie realizowany $^{19}$. Z ujęciem i werbalizacją charyzmatu w konstytucjach mieli problemy już sami założyciele instytutów zakonnych, co wskazuje na złożoność procesu oddania daru nadprzyrodzonego Ducha Świętego słowami ${ }^{20}$.

Ustalanie pewnych zasad prawych dla określonej wspólnoty na nic by się nie zdało, gdyby nie zostało ono następnie zwerbalizowane i przekazane adresatom w postaci odpowiednio zredagowanych zbiorów - na przykład konstytucji zatwierdzonych przez odpowiednią władzę kościelną. Język prawny ${ }^{21}$, w którym wyrażane są przepisy prawne, różni się znacznie od języka powszechnego. Jego cechą wyróżniającą jest charakter perswazyjny polegający na nakłanianiu i przekonywaniu adresatów do określonych zachowań dzięki zastosowaniu wypowiedzi powinnościowch ${ }^{22}$.

\footnotetext{
${ }^{19}$ P. Spiller, Charyzmat życia zakonnego $w$ Kościele, w: Formacja zakonna, t. 4, red. J. W. Gogola, Kraków 1998, s. 265.

${ }^{20}$ H. Koźmiński, Notatnik duchowy, red. G. Bartoszewski, Warszawa 1991, s. 185 : „Trudno wypowiedzieć ile czasu i pilności łożyłem na napisanie ustaw dla Felicjanek...przez lat około 30 byłem tym ciągle zajęty. 17 razy przerabiałem ich Konstytucje starając się, aby były coraz mniejsze - cały kufer mam zapakowany tymi pismami. Gdy posłałem je do Rzymu, kazano mi w Św. Kongregacji przerobić w innej formie; nie wiedząc o co chodzi, przerobiłem tak, że wprzódy były według Reguły Leona X, a potem ułożyłem w sposób racjonalniejszy.... Podobne prace podejmowałem przy urządzaniu Zgromadzeń ukrytych przez tyle lat prawie starając się, aby każde zgromadzenie miało odpowiednie dla siebie przepisy".

${ }^{21}$ Język prawniczy natomiast opisuje prawo, wypowiada się na temat mocy wiążącej przepisów prawnych, dokonuje interpretacji norm prawnych, ustala ich treść i ewentualność zastosowania w określonej sytuacji albo też traktuje o przestrzeganiu i skuteczności.

${ }^{22}$ P. Winczorek, т. Chauvin T. Stawecki, Wstęp do prawoznawstwa, Warszawa 2013, Wyd. 8, s. 66-75.
} 
Tekst prawny jest usystematyzowanym ciągiem ${ }^{23}$ wypowiedzi sformułowanych przez kompetentny podmiot $\mathrm{w}$ przewidzianej prawem formie, a następnie odpowiednio opublikowanych. Wewnętrzna spójność i niesprzeczność tekstu prawnego polega na tym, że poszczególne przepisy nie mogą pozostawać ze sobą w konflikcie. Swoistą cechą języka prawnego jest także specyficzne użycie w nim czasu teraźniejszego. Podmioty, które tworzą prawo, powinny zadbać o to, aby zapisane normy prawne odznaczały się jasnością i nie budziły wątpliwości ${ }^{24}$.

\subsection{Cechy języka prawnego}

Język zawarty w tekstach prawnych, nazywany często językiem prawodawcy, powinny cechować przede wszystkim adekwatność, komunikatywność i zwięzłość. Adekwatność przepisu polega na precyzyjnym jego sformułowaniu tak, aby wyrażał wiernie intencje prawodawcy. Pomocą w tym względzie jest stosowanie definicji, które w części dotyczącej instytutów życia konsekrowanego w KPK/1983 występują dość licznie, np. kanon 573 podaje definicję życia konsekrowanego, kanony 599-601 formułują pojęcia poszczególnych rad ewangelicznych oraz kan. 607, 603, 604, 710, 731 określają formy życia konsekrowanego w Kościele katolickim. Analogicznie także prawo własne instytutów zakonnych może zawierać podobne sformułowaniu.

Komunikatywności tekstu prawnego, czyli takiemu sformułowani $\mathrm{w}$ akcie normatywnym wzoru postępowania, aby był on dostatecznie zrozumiały dla odbiorców, a przede wszystkim dla adresatów norm prawnych, służy jego redakcja, a więc podział na odpowiednie części i rozdziały, punkty i paragrafy oraz właściwa, uzasadniona ich kolejność. Należy też unikać zawiłości tekstu. W tym celu powinno się zrezygnować z języka zbyt specjalistycznego i posługiwać się zdaniami prostymi, a nie wielokrotnie złożonymi. Ponieważ od stylu tekstu prawnego ważniejsza jest jego precyzyjność i jednoznaczność,

\footnotetext{
23 TAMŻE.

24 TAMŻE.
} 
konieczne są powtórzenia wyrazów, w tym przede wszystkim terminów fachowych i utartych określeń, dzięki czemu jedno zjawisko będzie miało jedną nazwę. Tekst można uznać za komunikatywny, jeżeli na jego zrozumienie odbiorca potrzebuje stosunkowo mało czasu.

Zwięzłość tekstu prawnego osiąga się z kolei m.in. dzięki unikaniu powtórzeń myśli, ozdobników, rezygnacji z wyrazów okazjonalnych i zamieszczaniu tylko sformułowań koniecznych do przekazania w sposób jednoznaczny norm postępowania.

W tekstach prawnych powinny dominować wypowiedzi o charakterze opisowym (czyli przedstawiające szczegóły wyglądu, funkcji i działania czegoś lub kogoś, przebiegu jakiegoś wydarzenia, charakteryzujące coś) oraz normatywnym (czyli ustalające przepisy, reguły i normy). Kształtowaniu odpowiedniego postępowania i skłanianiu do określonego zachowania służą takie określenia jak: należy, powinien (być, mieć, zachować), wolno/nie wolno, może/nie może (opuścić, pozostać), musi, a także stosowanie trybu rozkazującego, np. módlmy się/módlcie się/niech się modli/niech się modlą. W tekstach prawnych mogą też występować takie konstrukcje bezosobowe jak: zaleca się, zabrania się, wymaga się itp. oraz strona bierna, np. jest zobowiązany, powinien być nakłaniany.

\section{Redagowanie tekstu konstytucji według wskazań dokumentów kościelnych}

Do początku XX wieku nie wydano żadnych ogólnych norm dotyczących sposobu redagowania reguł i konstytucji zakonnych. Stolica Apostolska przy okazji zatwierdzania konstytucji zakonnych interweniowała pośrednio lub bezpośrednio w ich redakcję, dokonując różnego rodzaju zmian i modyfikacji, ale pozostawiając jednocześnie instytutom zakonnym dużą dowolność w ich opracowywaniu ${ }^{25}$.

\subsection{Normy z 1901 i 1921 roku}

Wraz z początkiem XX wieku zaczęła się kształtować praktyka redagowania konstytucji zgodnie $\mathrm{z}$ zasadami zawartymi w wydanych

${ }^{25}$ A. Montan, Costituzioni: attenzioni giuridiche, s. 172. 
w 1901 roku przez Kongregację Biskupów i Zakonników Normach dotyczących zatwierdzania przez Stolicę Apostolską instytutów zakonnych o ślubach prostych ${ }^{26}$. W dokumencie zalecano wykreślenie z tekstu konstytucji cytatów z Pisma Świętego, soborów, tekstów Ojców Kościoła, teologów i innych autorów lub ksiąg. Nie mogły też znajdować się w nich nauki ascetyczne, zachęty duchowe oraz uwagi mistyczne, dla których właściwym miejscem były oddzielne księgi ascetyczne. W 1921 roku wydano nowe Normy, które powielały zasady zawarte w poprzednim dokumencie ${ }^{27}$.

Konsty tucje zredagowane w sposób zalecony przez Stolicę Apostolską były niestety pozbawione elementów o charakterze teologicznym, duchowym oraz ascetycznym i ograniczały się jedynie do przepisów dotyczących zarządu instytutu, karności i sposobu życia członków. Nie oddawały więc one w pełni charyzmatu instytutu, który bowiem - jako rzeczywistość duchowa - domaga się także rozwinięcia teologicznego oraz nawiązania do myśli i zamiarów założycielii ${ }^{28}$.

\subsection{Kodeks Prawa Kanonicznego z 1983 roku}

Concilium Vaticanum II i dokumenty posoborowe w przeciwieństwie do wymienionych wyżej wskazań Stolicy Apostolskiej zalecały umieszczenie w konstytucjach zarówno elementów prawnych, jak

\footnotetext{
${ }^{26}$ S. C. Episcoporum et Regularium, Normae, secundum quas S. Congr. Episcoporum et Regularium procedere solet in approbandis novis institutis votorum simplicium, 28 iunii 1901, w: T. Schaefer, De religiosis ad normam Codicis Iuris Canonici, Roma $1947^{4}$, s. 1102-1134; także w: E. Sastre Santos, El ordenamiento de los institutos de votos simples según las Normae de la Santa Sede..., Apéndice documental, nr 57, s. 266-299 (odtąd: Normy).

27 S. C. De Religiosis, Normae secundum quas Sacra Congregati de Religiosis in novis religiosis congregationibus approbandis procedere solet, 6 martii 1921, AAS 13(1921), s. 312-319; a także w: E. Sastre Santos, El ordenamiento de los institutos de votos simples según las Normae de la Santa Sede (1854-1958), Roma-Madrid 19913, Apéndice documental nr 96, s. 350-356.

${ }^{28}$ KPK/1983, kan. 578; B. SzewCzUL, Troska Kościoła o zachowanie «patrimonium» przez instytuty życia konsekrowanego na podstawie dokumentów kościelnych z lat 1917-1996, Warszawa 2002, s. 260-262.
} 
i duchowych ${ }^{29}$, przy czym należało je tak zharmonizować, aby - jak czytamy w motu proprio Ecclesiae Sanctae - „nie sporządzić tekstu tylko prawnego albo w formie zachęty”, a więc pozbawionego określeń o charakterze powinnościowym ${ }^{30}$. Zastrzeżenie to, aktualne również obecnie, tj. podczas rewizji konstytucji, dotyczy niebezpieczeństwa popadnięcia w drugą skrajność polegającą na tym, że zrywając z nazbyt jurydycznym charakterem kodeksu fundamentalnego, pomijano przepisy prawne na rzecz zasad życia duchowego i ascetycznego, co zbliżało konstytucje do poradników duchowych i podręczników mistyki ${ }^{31}$. W ten sposób dochodziło do utraty zalecanej przez dokumenty soborowe i posoborowe równowagi między kwestiami prawnymi i duchowymi.

Trzeba podkreślić, że również KPK/1983 w trosce o wierne oddanie dziedzictwa instytutu i jego charyzmatu oraz umożliwienie członkom instytutu życia według nich ponawia wymóg połączenia w konstytucjach elementów duchowych i prawnych, nie pozwalając na mnożenie norm prawnych bez potrzeby ${ }^{32}$.

${ }^{29}$ PC 2b; Ecclesiae Sanctae 12: „Ogólne ustawy każdego Instytutu zakonnego (Konstytucje, Typiki, Reguły, czy inaczej nazwane) zawierają mniej więcej te elementy: a) Zasady ewangeliczne i teologiczne o życiu zakonnym i jego zespoleniu z Kościołem, oraz odpowiednie i pewne słowa, w których „uznaje się i zachowuje ducha i właściwe zamiary Założycieli, a także zdrowe tradycje, co w sumie stanowi dziedzictwo każdego Instytutu zakonnego"

b) przepisy prawne konieczne do jasnego określenia charakteru, celów i środków Instytutu; nie należy mnożyć tych przepisów, ale zawsze powinno się wyrazić je adekwatnie".

${ }^{30}$ Ecclesiae Sanctae 13: „Konieczne jest zjednoczenie obydwu czynników, mianowicie duchowego i prawnego, by zasadnicze kodeksy Instytutów posiadały trwałą podstawę i by przepajał je prawdziwy duch i życiowy przepis; wystrzegać się zatem należy, by nie sporządzić tekstu albo tylko prawniczego, albo jedynie w formie zachęty".

${ }^{31}$ G. RoccA, Regola. VI, Le «costituzioni» delle congregazioni moderne, Dizionario degli Istituti di Perfezione, vol. VII, Roma 1973, col. 1439.

${ }^{32} \mathrm{KPK} / 1983$, kan. 587 § 3: „W tym kodeksie należy odpowiednio zharmonizować elementy duchowe i prawne; przy czym jednak nie powinno się mnożyć norm prawnych bez konieczności”; E. DE Montebello, Le costituzioni di un Istituto religioso, Quaderni di Diritto Ecclesiale 3(1990) nr 1, s. 217. 


\subsubsection{Zharmonizowanie elementów prawnych i duchowych konstytucji}

Można powiedzieć, że konstytucje są dokumentem „prawa duchowego", w którym prawo i chryzmat integrują się w celu ułatwienia każdemu członkowi instytutu i całemu instytutowi rozpoznania i pełnienia woli Boga ${ }^{33}$. W pozostałych kwestiach współczesny prawodawca pozostawia instytutom pewną swobodę w redagowaniu konstytucji.

Wymiar duchowy konstytucji potwierdza kanon 587 § 3 KPK/1983 ustalający, że kodeks fundamentalny instytutu powinien zawierać elementy duchowe ${ }^{34}$. Jest to konsekwencja przekonania, iż najwyższą normę życia zakonnika stanowi naśladowanie Chrystusa ukazane w Ewangelii i wyrażone w konstytucjach własnego instytutu, a podstawowym jego obowiązkiem powinna być kontemplacja rzeczywistości Bożej oraz zjednoczenie z Bogiem w modlitwie ${ }^{35}$.

Tak więc elementy duchowe powinny stanowić źródło dla wszystkich norm konstytucji oraz innych zbiorów prawa własnego i przenikać je, a zasada ta dotyczy również sprawowania władzy, zarządzania dobrami materialnymi i innych kwestii ${ }^{36}$.

\subsubsection{Kwestie do zamieszczenia}

w zbiorach prawa własnego instytutu

$\mathrm{W}$ trosce o zachowanie tożsamości przez poszczególne instytuty prawodawca poleca, aby w kodeksie fundamentalnym, czyli konstytucjach każdego instytutu, oprócz tego, co nakazuje zachować kan. $578^{37}$, zamieścić także normy dotyczące zarządzania instytutem,

\footnotetext{
${ }^{33}$ G. Ghirlanda, Carisma di un istituto di vita consacrata, Vita Consacrata 48(2012), s. 38-39.

${ }^{34}$ B. BAroffio, Presentazione e assimilazione delle costituzioni, Informationes SCRIS 9(1983), nr 1, s. 167.

${ }^{35}$ KPK/1983, kan. 662, 663.

${ }^{36}$ Posługa władzy i posłuszeństwo, nr 3; E. De Montebello, Le costituzioni di un Istituto religioso, s. 215.

${ }^{37}$ KPK/1983, kan. 578: „Wszyscy powinni wiernie zachowywać myśl i zamierzenia założycieli, zatwierdzone przez kompetentną władzę kościelną, dotyczące natury,
} 
dyscypliny członków, ich włączania oraz formacji, jak również przedmiotu podejmowanych świętych więzów i wyłączania z instytutu. Wymienione przez prawodawcę zasadnicze kwestie, których nie można pominąć w konstytucjach, obejmują bogaty wachlarz zagadnień $^{38}$. Podstawowe rozdziały mogą przyjąć następujące nazwy: natura i cel instytutu, konsekracja zakonna, nasze życie z Bogiem, życie we wspólnocie, apostolat, formacja członków, ogólne zasady dotyczące formacji, poszczególne etapy formacji (postulat, nowicjat, juniorat, formacja permanentna), odpowiedzialni za formację, profesja wieczysta, ponowne przyjęcie do instytutu, zarząd instytutu, władza w instytucie, kapituła generalna, zarząd generalny, zarząd prowincji lub regionu, władza lokalna, zarządzanie dobrami doczesnymi, wyłączanie członków z instytutu, przestrzeganie konstytucji ${ }^{39}$.

Pozostałe normy wydawane przez władzę instytutu winny być zebrane w kodeksach drugorzędnych odpowiednio często odnawianych i przystosowywanych do wymagań miejsca i czasu ${ }^{40}$.

\section{Zakończenie}

Posoborowe pokolenia zakonników, dostosowując prawo własne do wymagań Concilium Vaticanum II, szukało wciąż doskonalszych form wyrażania charyzmatu instytutu, pragnąc uzupełnić „braki” założycieli w tym względzie i stworzyć konstytycje-perełkę. Może dlatego obowiązujące posoborowe konstytucje, kilkakrotnie nowelizowane, opracowane w formie bogatej i nienagannej pod względem teologicznym oraz duchowym, mimo wszystko słabiej przemawiają

celu, ducha i charakteru instytutu, jak również zdrowych jego tradycji, co stanowi dziedzictwo tegoż instytutu”.

${ }^{38}$ KPK/1983, kan. 587 \$1; J. KAŁOWsKI, Konstytucje jako zabezpieczenie celu i zadań instytutów życia konsekrowanego, Prawo Kanoniczne 36 (1993) nr 3-4, s. 5-19; Tenże, Konstytucje i inne zbiory prawne instytutów życia konsekrowanego według Kodeksu Prawa Kanonicznego, Prawo Kanoniczne 29 (1986) nr 1-2, s. 149-184.

${ }^{39}$ Congregatio pro Istitutis Vitae Consecratae et Societatibus Vitae Apostolicae, Schema generale circa la redazione delle costituzioni, Vaticano 1999, s. $1-4$.

${ }^{40}$ KPK/1983, kan. $\$ 4$. 
do zakonnika niż te wcześniejsze, które przekazały odruchy serca założyciela, nie dusząc ich zbytnio w przesadnej teologii ${ }^{41}$.

Właściwe połączenie elementów duchowych i prawnych w konstytucjach instytutów zakonnych sprawia, że oddają one w pełni charyzmat instytutu oraz całokształt życia zakonników stosujących się do nich i stają się dla nich prawdziwą regułą życia ${ }^{42}$. Tak opracowany kodeks fundamentalny odzwierciedla dominujący element charyzmatu, jakim jest „żar przenikający do głębi duszę, która pragnie się upodobnić do Chrystusa, aby dawać świadectwo o wybranym aspekcie Jego tajemnicy"43. Ten bardzo ważny aspekt życia zakonników może się urzeczywistnić i rozwinąć w tradycji insty tutu tylko $\mathrm{w}$ zgodzie $\mathrm{z}$ właściwie zredagowanymi konstytucjami i innymi zbiorami prawa własnego.

\section{Validity of the revision of the religious institutes' constitutions, as well as their contents and form in light of Church documents}

Basic norms of the religious institutes of the consecrated life, usually called constitutions, should comprise basic theological rules and law norms, which faithfully reflect institutes' charisma and their spiritual patrimony. Each religious is obliged to faithfully preserve, develop and safeguard the patrimony of his own institute concerning its nature, purpose, character, spirit and sound traditions (Can. 578 CCL/1983). This way he will strive for perfect love of God by way of evangelical counsels following the method shown by founders inspired by the Holy Spirit. That's why the faithful and communicative expressing of founders thoughts, and intentions in constitutions are so important. Constitutions are not simple book, which is put aside on the shelf, when it was already read, but must become real book of life for religious, and which contents they must constantly absorb, and implement into their own spiritual life and everyday activities. Therefore

\footnotetext{
${ }^{41}$ P.G. CABRA, Rinnovamento in atto della vita religiosa, w: AA.VV., Rinnovamento e futuro della vita religiosa, Roma 1978, s. 68; TenżE, Essere religiosi, Brescia 1978, s. 41 .

${ }^{42}$ Ancelle della Carità, Constitutzioni. Libro della vita, Brescia 2009.

${ }^{43}$ Vita consecrata 36.
} 
a manner of formulating the basic questions of constitution, and their language play very important role.

SŁOWA KLUCzowe: konstytucje, prawo własne, rewizja, elementy prawne, elementy duchowe, kapituła generalna

KEY wORDs: constitutions, own law, revision, juridical elements, spiritual elements, general chapter

Nota o Autorze:

S. DR hab. Bożena SzewCzul WNO, PRof. UKSW - profesor nadzwyczajny na Wydziale Prawa Kanonicznego UKSW w Warszawie, kierownik zakładu Kanonicznych Forma Życia Konsekrowanego w katedrze Ustroju Kościoła i Kanonicznych Form Życia Konsekrowanego. 